\title{
An Empirical Study into the Role of Quality Factors in Influencing the Effectiveness of the E-learning System: An Academic Staff Perspective
}

\author{
Abdulhameed Rakan Alenezi \\ Instructional Technology, Faculty of Education \\ Jouf University \\ Kingdom of Saudi Arabia
}

Received: May 11, 2021. Revised: December 2, 2021. Accepted: December 13, 2021. Published: January 7, 2022.

\begin{abstract}
COVID-19 has caused the closure of schools around the world. According to the Global World Forum, more than 1.2 billion students have dropped out of classrooms worldwide. As a result, education has transformed dramatically with the extensive rise in elearning where teaching is delivered remotely through technological solutions and platforms. Even though successful transitions among many universities have taken place, the users' expectations of e-learning systems are still poor due to this rapid movement. Therefore, e-learning systems need to be investigated from a perspective of quality in order to ensure its effectiveness. The aim of this study is to empirically investigate the role of quality factors in influencing the effectiveness of e-learning systems from the perspective of academic staff. A quantitative approach was adopted using a web-based questionnaire. A total of 129 valid questionnaires were obtained through simple random sampling techniques. The results of the study indicated that all examined factors, namely, System Quality (SQ), Information Quality (IQ), Service Quality (SEQ), Technical Support Quality (TSQ), Course Design Quality (CDQ), and Learner Quality (LQ), influenced E-learning System Effectiveness significantly. The proposed factors explained a significant percentage with 90.8 percent of the total variance of E-learning Effectiveness. Furthermore, the results of multiple regressions using stepwise analysis indicated that the top three contributing factors were Service Quality, Learner Quality, and System Quality respectively. Moreover, the results revealed that Attitude partially mediated the relationship between Service Quality and E-learning System Effectiveness. Several implications and recommendations were proposed for future research.
\end{abstract}

Keywords- E-learning System Effectiveness, System Quality, Information Quality, Service Quality, Technical
Support Quality, Course Design Quality, Learner Quality, Attitude

\section{INTRODUCTION}

A $\mathrm{S}$ a result of the COVID-19 outbreak, the face of the education system has digitally transformed worldwide. Therefore, many universities have been forced to adopt technology-based learning such as learning portals, learning management systems, mobile applications, video conferencing, and satellite educational channels in order to overcome the dramatic impacts of the pandemic [1]. There are no doubts about the need to evaluate E-learning System Effectiveness; quality-related issues are still more critical in both practice and research during this pandemic [2] - [3].

The unexpected transition to an electronic mode of learning in education has resulted in many critical issues, among them their effectiveness and educational quality [1]. Therefore, research and many studies have investigated the critical issues related to e-learning systems such as usage, acceptance, and adoption [2]-[4]-[5]. Nonetheless, investigations into the quality factors that affect E-learning System Effectiveness are still limited [6]. The pandemic has greatly changed the nature of critical success factors related to using e-learning systems effectively due to sudden transformation and many external factors that have interfered in the learning process and ultimately affected the quality of learning outcomes [7]. Yet a substantial number of studies have focused on the factors

\section{PROBLEM STATMENT}

The rapid growth of online courses during the COVID-19 pandemic has exhausted E-learning System Effectiveness [5]. Even though much research has empirically focused on elearning system-related issues from the adoption, acceptance, satisfaction, and accessibility perspectives [8] - [9] - [10] - [4] - [11], unfortunately, limited research has addressed the issues related to the quality of e-learning systems [12] as well as their 
effectiveness [13]. The benefits obtained from integrating elearning systems as an educational approach during this pandemic were achieved and, ultimately, the problem of university closures was mainly solved [14]. However, issues attached to the quality of e-learning systems have been raised [13]-[7]-[6]. E-learning systems are considered as information system platforms which deign to facilitate the learning activities and interactions between students and educators [15]. Therefore, the ISS Model by DeLone and McLean is considered to be among the best models that can predict the quality factors that could affect e-learning systems and is thus widely applied in this area [17]- [13]- [18]- [19]. Hence, this research will try to address the role of the quality factors that affect E-learning System Effectiveness during the pandemic by adopting the ISS Model [20]. Furthermore, additional factors will be investigated such as Learner Quality, Course Design Quality, and Technical Support Quality as they are associated with E-learning System Effectiveness [21]. In the literature, Attitude has been indicated as a significant factor that measures E-learning System Effectiveness [22] - [23] - [24]. Nevertheless, E-learning System Effectiveness could be influenced negatively if Attitude is absent [24]. Thus, the mediating effect of Attitude will be also investigated.

\section{LITERATURE REVIEW}

\section{A. E-learning and the COVID-19 Pandemic}

The COVID-19 pandemic has dramatically changed educational systems worldwide [25]. Globally, approximately 1.048 billion students $(60 \%)$ of total enrolled students have been banned from practicing traditional learning activities due to universities closures according to UNSCO. Therefore, the variety of e-learning platforms has become a means to continue education and ensure active learning through interactions between students and educators. As a result of this, many universities have faced challenges associated with issues such as successful transformation, quality assurance, and system capabilities. Reference [2] point out that e-learning system can be used successfully only if the current systems are evaluated and the problems that are being encountered are highlighted. According to [13] the global market for e-learning was approximately $\$ 176$ billion in 2017 and is predicted to rise to $\$ 398$ billion by 2026 . The COVID-19 pandemic has significantly expanded the e-learning market, which was estimated to be worth $\$ 103.8$ billion in 2019 [13].However, the COVID-19 pandemic has increased the market size of elearning to be valued at $\$ 103.8$ billion in 2019 [13]. Nevertheless, in spite of the fact that major investments have been made in e-learning systems, certain universities have not benefitted from its introduction for several [26]. Fortunately, Higher Education Institutions in Saudi Arabia have advanced experience in using e-learning systems; therefore, many challenges related to their usage such as readiness, acceptance, and infrastructure do not exist [21] -[11]. According to the World Bank [27], the Ministry of Education in Saudi Arabia has presented five different choices besides virtual learning, among them educational portals, Satellite Education channels, social networking, and mobile applications. However, limited research related to e-learning issues in Saudi Arabia has been conducted during the pandemic [28]-[7]-[6]-[4]-[11]. Nonetheless, researchers intend to investigate the e-learning transition and related critical success factors. Therefore, the importance of the study of quality-related factors has become crucial to ensure effective learning and satisfaction [13].

The study of [11] assessed e-learning and the role it plays in education and focuses in particular on the way in which elearning can be harnessed to address the interruptions in education caused by the outbreak of the global pandemic. A survey of teachers' preferences in relation to various features of e-learning found that 86 per cent of teachers had a positive attitude toward e-learning, and many noted that it reduced the time and effort spent editing and modernizing educational resources. Only 14 per cent of teachers saw e-learning in a negative light, since they were not confident that they would be able to use it effectively and reported that they did not have the technological knowledge to implement e-learning. Furthermore, reference [7] examined the successful critical factors related to e-learning implementation during the pandemic from a managerial point of view. The researchers interviewed sixty-nine e-learning managers in different educational institutions. The study concluded that a number of factors have affected learning usage during the pandemic, namely, technology management, administrative support, student recognition of the benefits of e-learning, and high levels of IT proficiency on the part of instructors, students, and universities alike. Blended learning was found to be the most effective of the five systems. The study showed that even if an educational institution had acquired cutting-edge technology, the use of e-learning during COVID-19 depended to a great extent on whether those involved were ready to implement it. Study of [4] set out to evaluate students' views of e-learning for English as a second language in Saudi Arabian universities during the pandemic, and the results which were based on a qualitative and comparative methodology demonstrated that students of English as a second language had positive attitudes toward e-learning in Saudi Arabian universities and found many advantages and very few disadvantages in e-learning.

\section{B. E-learning System Effectiveness}

The term "effectiveness" is defined as the precision and comprehensiveness with which users can achieve certain objectives as indicated by the quality of the solution and error rates [29]. E-learning System Effectiveness evaluation is still a critical issue due to measurement variances [24]. Besides that, the effectiveness typically associated with very significant terms like efficiency and satisfaction is widely investigated in relation to system success and usability [30] - [31]. Unfortunately, although COVID-19 has increased investment in e-learning systems, some universities are still not attaining the expected benefits of using e-learning systems [13]. Moreover, among those benefits is system effectiveness, which correlated significantly to most users' crucial success factors such as accessibility, interactivity, perception, satisfaction, costiveness, and usability [17]- [32]- [33]- [34]- [35]. 
A study undertaken by [17] evaluated the successful usage of e-learning systems using four approaches. An inclusive model was created by integrating the ISS model with TAM, satisfaction models of e-learning, and quality models of elearning. The results determined that perceived satisfaction with e-learning were affected by the quality of the technical system, the quality of the information, the quality of the service, the quality of the support system, the quality of the learner, the quality of the instructor, and perceived usefulness. Taken together, these factors provide an explanation for the 71.4 percent of the total variance of perceived satisfaction. Perceived usefulness was found to be driven by the quality of the technical system, the quality of the information, the quality of the support system, the quality of the learner, and the quality of the instructor, which accounted for 54.2 percent of the variance of perceived usefulness. According to the authors, there are four constructs which influence of the use of elearning, namely, the quality of the educational system, the quality of the support system, the quality of the students, and the perception of usefulness. Study of [35] investigated the implementation of e-learning in South Korea by integrating the perspectives of effectiveness and legitimacy which take into account the effectiveness of e-learning. The authors found that effectiveness is significantly heightened by creating a robust elearning infrastructure and ensuring that its standardization is regularly reviewed, since it is considered as key to the usage and effectiveness of e-learning systems.

In addition, the research of [33] conducted research into the effectiveness of e-learning portals by using a structural equation model (SEM). They found that the quality of the system and service had a far greater impact on the successful usage of e-learning rather than the quality of information. In addition, the researchers determined that the quality of the system, service, and information of e-learning systems play a major role in shaping user satisfaction and effectiveness.

\section{Information System Success (ISS) Model by Delone \& Mclean as a Theoretical Foundation}

The first introduction of the ISS model was in 1992 by DeLone \& McLean. The ISS model is made up of six factors that measure the success of information systems. The model consists of six variables, namely, system quality, information quality, satisfaction, use, individual impact, and impact on the organisation, as shown in Figure 1.

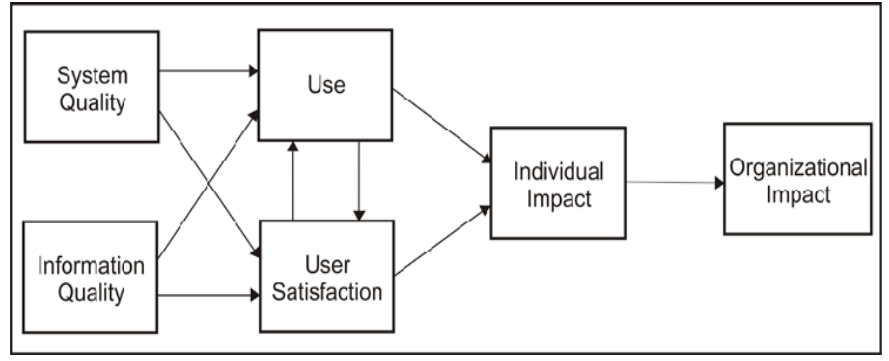

Fig. 1 ISS model (1992)

The ISS model was validated, developed, and updated in 2003 to include an additional factor: quality of service. Furthermore, intention to use has been added to the use factor and both individual and organisational influence was compounded into a single parsimonious factor termed Net Benefits, as depicted in Figure 2.

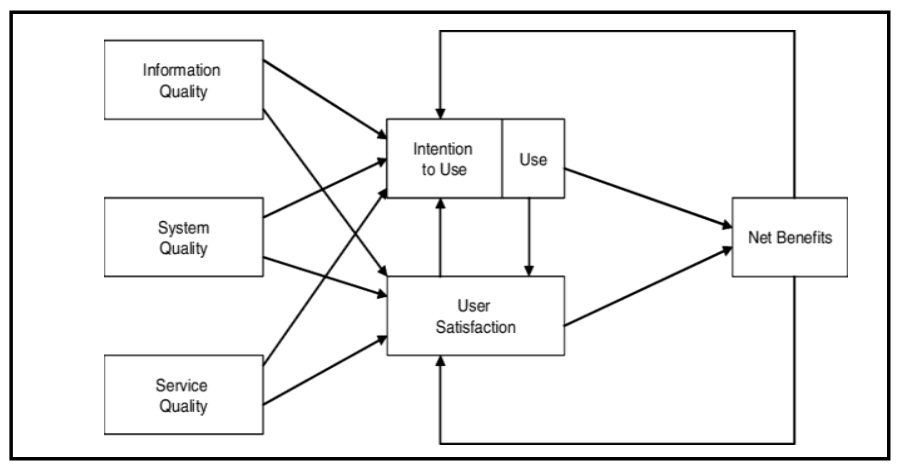

Fig. 2 DeLone and McLean Updated ISS Model (2003)

Despite the fact that there are many other adopted IS and Technology models and theories in the literature such as the Theory of Reasoned Action (TRA), Technology Acceptance Model (TAM), Theory of Planned Behaviour (TPB), and Unified Theory of Acceptance and Use of Technology (UTAUT), the DeLone \& McLean ISS model still one of most cited models in the area of information systems [36]. The Elearning Management System (LMS) is considered basically as an Information System [13]. Moreover, as a result of the nature of the objectives of this research, which empirically investigates the effect of quality factors on E-learning System Effectiveness, the ISS model has been chosen as the foundation model for this research.

\section{Learner Quality}

The learner's quality was found to be an integral part of Elearning System Effectiveness [17] - e-learning is a selfdirected mode of education which demands characteristics such as time management and autonomy from the learners. Therefore, several e-learning models have embedded learner quality-related factors in their proposed models. A research of [17] has proposed learner quality as the main factor in their EESS model. The study revealed that, empirically, learner quality is a strong predictor of e-learning success and effectiveness.

\section{E. Course Design Quality}

Cheng (2020) has investigated the roles of interactivity and course quality factors in influencing the effectiveness of cloudbased e-learning systems. The results indicated that the course design quality contributed positively and significantly to influencing the effectiveness of and satisfaction toward elearning systems. Furthermore, many studies have proposed and proved the importance influence of course design quality on the effectiveness usage of e-learning systems [21] - [37] [38]. Therefore, the current research would investigate the influence of course design on e-learning effectiveness. 


\section{F. Technical Support Quality}

Technical support quality for both students and academic staff is considered an essential part of any successful implementation of e-learning courses and quality [21] - [39]. The National eLearning Centre (2020) has provided national standards for public education institutions in Saudi Arabia in order to control online learning quality. Technical support was a significant part of their standardization. The works of [40] indicated, in their study of the state of Online Learning, that elearning courses should provide adequate technical assistance for the faculty. This is consistent with the recent research of [41] in their investigation of the factors influencing e-learning quality during the pandemic, which indicated that technical support is a significant factor for and positively associated with the quality of e-learning. Thus, technical support quality was investigated as a critical factor that could affect E-learning System Effectiveness.

\section{G. Attitude}

Attitude has been extensively investigated and substantiated to be a significant factor in influencing human behaviour in many technology models and theories such as the Theory of Planned Behaviour (TPB) and the Technology Acceptance Model (TAM) [42]. Moreover, Attitude has been found to be significant in predicating E-learning System Effectiveness [22] - [23] - [43]. Several studies which extended the ISS Model [20] have integrated other models such as TAM in order to investigate the significant effect of attitude in e-learning environments [44] - [45]. In particular, Service Quality has been found to be significantly associated with Attitude in using the online environment and new technology [46] - [47]. However, [24] stated that E-learning System Effectiveness could be significantly influenced by Attitude even if the system is rich with System and Service Quality. Therefore, the mediating effect of Attitude on the relationship between Service Quality and E-learning System Effectiveness would be investigated.

\section{Research Model DeVelopment AND Proposed HYPOTHESES}

\section{A. Research Model Development}

The proposed model in the current research has primarily adopted the DeLone \& McLean ISS Model constructs, namely, System Quality (SQ), Information Quality (IQ), and Service Quality (SEQ), and has extended it to include additional significant factors, namely, Technical Support Quality (TSQ), Course Design Quality (CDQ), and Learner Quality (LQ). The direct influence of the proposed factors towards E-learning System Effectiveness has been investigated. Nevertheless, the mediating effect of Attitude (ATT) on the relationship between Service Quality (SEQ) and E-learning System Effectiveness has also been investigated due to its significant role in determining the effectiveness of e-learning as depicted in Figure3.

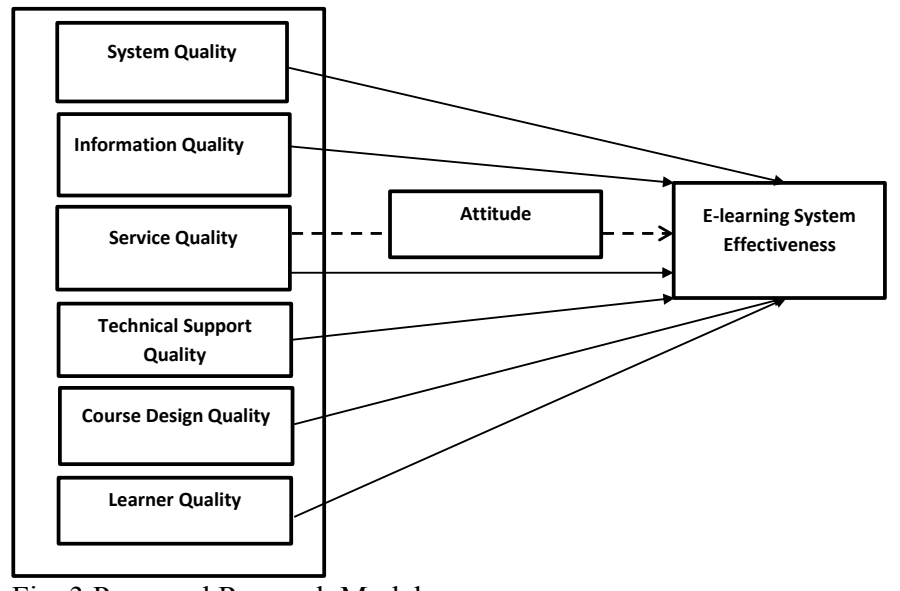

Fig. 3 Proposed Research Model

\section{B. Research Questions \& Hypotheses}

Based on the objectives of the study, which are to examine the role of the Quality factors in influencing E-learning System Effectiveness and to empirically examine the proposed research model, three main research questions were proposed:

1- What are the Quality factors that could influence E-learning System Effectiveness?

2- What are the most contributed Quality factors for E-learning System Effectiveness?

3-Does Attitude mediate the relationship between Service Quality and E-learning System Effectiveness?

Based on the literature discussed above, the research questions, and the proposed research model, several hypotheses were formulated:

H1: System Quality has a positive influence on E-learning System Effectiveness.

$\mathrm{H} 2$ : Information Quality has a positive influence on E-learning System Effectiveness.

H3: System Quality has a positive influence on E-learning System Effectiveness.

H4: Technical Support Quality has a positive influence on Elearning System Effectiveness.

H5: Course Design Quality has a positive influence on Elearning System Effectiveness.

H6: Learner Quality has a positive influence on E-learning System Effectiveness.

H7: Attitude mediates positively the relationship between Service Quality and E-learning System Effectiveness.

\section{Instrument Development}

Based on the literature review of related [21] - [42] - [17] - [33] [20], a questionnaire was prudently developed in order to achieve the research objectives. The questionnaire consisted of two sections: demographic questions and proposed factors. 49 items were developed to measure the proposed factors, namely, System Quality (SQ), Information Quality (IQ), Service Quality (SEQ), Technical Support Quality (TSQ), Course Design Quality (CDQ), Learner Quality (LQ), and Attitude (ATT). The questionnaire utilized a fourpoint Likert scale from 1 (strongly disagree) to 4 (strongly agree). Table 1 shows the main factors, number of items, and related references. 
Table 1.Proposed Factors, Number of Items, and Sources

\begin{tabular}{ccc}
\hline Proposed Factors & No. of items & Sources \\
\hline System Quality & 8 & Delone \& McLean, 2003 \\
Information Quality & 6 & Delone \& McLean, 2003 \\
Service Quality & 5 & Delone \& McLean, 2003 \\
Technical Support Quality & 6 & Alenezi, 2017b \\
Course Design Quality & 9 & Alenezi, 2017b \\
Learner Quality & 6 & Al-Fraihat, Joy \& Sinclair, 2020 \\
Attitude & 3 & Alenezi, 2017a \\
E-learning System Effectiveness & 6 & Chopra et al., 2019 \\
Total & 49 & \\
\hline
\end{tabular}

\section{Sampling and Research Design}

The research has applied a quantitative approach using the questionnaire method as a primary tool for collecting the data. A simple random sampling technique was utilized in this research. The questionnaire was distributed electronically to the academic staff from different colleges at Jouf University during the first semester in the academic year of 2021-2022. Uncompleted questionnaires were eliminated and a total number of 129 valid responses were obtained and utilized for the further analysis of data.

\section{E. Validity of Instrument}

- Face and content validity

Face and content validity is the determination of the extent to which the instruments are able to measure what are supposed to be assessed. Therefore, the initial questionnaire was sent to three bilingual experts in the field of instructional technology. The experts have provided some comments and observations which made the questionnaire clearer and valid so as to achieve the research objectives.

\section{- Reliability analysis of instruments}

The reliability analysis of instruments was performed using the Cronbach alpha technique to determine the reliability for each scale. Internal consistency was detected using corrected item-total correlation. The Cronbach alpha coefficient greater than 0.70 was considered as adequate [48] and the acceptable cut-off level of the total corrected item correlation should be above 0.30 [49]. Table 2 shows that all the factors were above the acceptable cut-off levels $(>0.70 ;>0.30)$, which was considered statistically acceptable.

\begin{tabular}{|c|c|c|c|}
\hline Factors & $\begin{array}{l}\text { \# of } \\
\text { Items }\end{array}$ & $\begin{array}{c}\text { Corrected Item-total } \\
\text { Correlation }(>\mathbf{0 . 3}) \\
\end{array}$ & Cronbach's Alpha $(\alpha)(>0.70)$ \\
\hline System Quality & 8 & $\begin{array}{c}0.53,0.80,0.83 \\
0.61,0.81,0.71 \\
0.60,0.56\end{array}$ & 0.89 \\
\hline Information Quality & 6 & $\begin{array}{c}0.63,0.72,0.69,0.56 \\
0.63,0.66\end{array}$ & 0.86 \\
\hline Service Quality & 5 & $\begin{array}{c}0.70,0.58,0.82,0.81, \\
0.60\end{array}$ & 0.87 \\
\hline Technical Support Quality & 6 & $\begin{array}{c}0.66,0.65,0.82,0.79 \\
0.57,0.72\end{array}$ & 0.88 \\
\hline Course Design Quality & 9 & $\begin{array}{c}0.58,0.60,0.74,0.75 \text {, } \\
0.59,0.60,0.65,0.55, \\
0.40\end{array}$ & 0.87 \\
\hline Learner Quality & 6 & $\begin{array}{c}0.86,0.91,0.93,0.92 \\
0.90,0.79\end{array}$ & 0.84 \\
\hline Attitude & 3 & $0.62,0.73,0.81$ & 0.85 \\
\hline $\begin{array}{l}\text { E-learning System } \\
\text { Effectiveness }\end{array}$ & 6 & $\begin{array}{c}0.55,0.75,0.80,0.65 \\
0.54,0.63\end{array}$ & 0.86 \\
\hline
\end{tabular}

\section{- Factor Analysis}

Factor analysis was performed to check the accuracy of the measurement. The research sample size of 129 was acceptable, given that the minimum cut-off level is set at 100 [50]. In addition, a cut-off value of 0.30 was applied to the matrix correlation coefficients [48]. Bartlett's test of sphericity was deemed significant when Kaiser-Meyer-Olkin exceeded 0.50 . The factor loadings of 0.50 were judged to be acceptable.

Table 3.Proposed Factors, Number of Items, and Sources

\begin{tabular}{|c|c|c|c|c|c|c|c|c|}
\hline Items & $\begin{array}{l}\mathrm{SQ} \\
\text { (8 items) }\end{array}$ & $\begin{array}{l}\text { IQ } \\
\text { (6 items) }\end{array}$ & $\begin{array}{l}\text { SEQ } \\
\text { (5 items) }\end{array}$ & $\begin{array}{l}\text { TSQ } \\
\text { (6 items) }\end{array}$ & $\begin{array}{l}\text { CDQ } \\
\text { (9 items) }\end{array}$ & $\begin{array}{l}\mathrm{LQ} \\
\text { (6 items) }\end{array}$ & $\begin{array}{l}\text { ATT } \\
\text { (3 items) }\end{array}$ & $\begin{array}{l}\text { ESE } \\
\text { (6 items) }\end{array}$ \\
\hline \multirow{4}{*}{$\begin{array}{l}\text { Exploratory } \\
\text { factor analysis } \\
\text { (EFA) }\end{array}$} & .898 & .823 & .908 & .898 & .848 & .845 & .922 & .888 \\
\hline & .890 & .804 & 906 & .863 & .845 & .779 & .879 & .850 \\
\hline & .875 & .762 & .786 & .802 & .737 & .773 & .835 & .778 \\
\hline & .795 & .753 & .775 & .793 & .721 & .738 & & .748 \\
\hline \multirow{4}{*}{$\begin{array}{l}\text { (Factor } \\
\text { loading) }\end{array}$} & .716 & .752 & .684 & .761 & .703 & .699 & & .693 \\
\hline & .662 & .711 & & .664 & .675 & .629 & & .658 \\
\hline & .658 & & & & .671 & & & \\
\hline & .613 & & & & .619 & & & \\
\hline $\begin{array}{l}\text { Total } \\
\text { variance } \\
\text { explained }\end{array}$ & 58.81 & 59.22 & 67.73 & 64.60 & $\begin{array}{l}.575 \\
50.77\end{array}$ & 56.67 & 76.92 & 59.70 \\
\hline KMO & 0.808 & 0.749 & 0.815 & 0.776 & 0.792 & 0.820 & 0.670 & 0.847 \\
\hline $\begin{array}{l}\text { Bartlett's test } \\
\chi^{2}\end{array}$ & 1084.608 & 567.178 & 362.486 & 534.687 & 673.435 & 296.232 & 192.408 & 375.028 \\
\hline p. & .000 \%* & $.000 \%$ & $.000^{* * *}$ & $.000^{* * *}$ & $.000^{* * *}$ & $.000 \%$ & $.000 \%$ & \\
\hline
\end{tabular}

Table 3 illustrates that the examined variables of exploratory factor analysis (EFA) demonstrated acceptable levels of KMO, that is, above 0.50 , and the sphericity test was significant for every measured variable $(\mathrm{p}<.05)$. The examined variables provided an explanation for high total variance and showed acceptable and high factors loading, since every examined article demonstrated an average which was greater than 0.30, the acceptable cut-off level for this research [48]. As a result, the projected variables meet the criteria for regression analysis.

\section{DATA ANALYSIS AND DISCUSSION}

The data was analysed by using the most up-to-date version of SPSS. The profiles of the respondents were useful in helping the researcher to understand the sample characteristics in this 
study which, in turn, would allow the researcher to explain the differences in the measurements of the respondents.

\section{A. Profile of Respondents}

In order to clarify the sample characteristics, the total numbers of participants in the research were 129 academic staff from Jouf University during the academic year of 2020-2021. A total of $48.8 \%$ were male $(\mathrm{N}=63)$ and $52.2 \%$ were female $(\mathrm{N}$ $=66$ ). The majority of the participants' age was between 26 and 30 , which represented about $44.2 \%$ of total respondents. The rank of the majority of the respondents was Assistant Professor $(42.6 \%)$. Table 4 summarizes the frequency and percentage of the respondents' profiles.

Table 4. The Frequency and Percentage of the Respondents' Profiles

\begin{tabular}{llcc}
\hline Profile & & Frequency & Percentage \\
\hline Gender & $\mathrm{M}$ & 63 & $48.8 \%$ \\
& $\mathbf{F}$ & $\mathbf{6 6}$ & $\mathbf{5 2 . 2 \%}$ \\
\hline Age & $<25$ & 34 & $26.4 \%$ \\
& $\mathbf{2 6 - 3 0}$ & $\mathbf{5 7}$ & $\mathbf{4 4 . 2 \%}$ \\
& $31-40$ & 22 & $17.1 \%$ \\
& $>41$ & 16 & $12.4 \%$ \\
\hline Academic rank & Professor & 3 & $2.3 \%$ \\
& Associate Professor & 28 & $21.7 \%$ \\
& Assistant Professor & $\mathbf{5 5}$ & $\mathbf{4 2 . 6 \%}$ \\
& Lecturer or Instructor & 43 & $33.3 \%$ \\
\hline College & Medical \& Health Colleges & 38 & $29.5 \%$ \\
& Humanity \& Management College & $\mathbf{5 3}$ & $\mathbf{4 1 . 1 \%}$ \\
& Education College & 36 & $27.9 \%$ \\
& Community College & 2 & $1.6 \%$ \\
\hline Total & & $\mathbf{1 2 9}$ & $\mathbf{1 0 0 \%}$ \\
\hline
\end{tabular}

\section{B. Answering Research Questions and Hypotheses Testing}

In order to answer the first research question, what are the Quality factors that could influence E-learning System Effectiveness, six hypotheses were formulated as indicated earlier. A product-moment correlation analysis was also performed to examine the direct relationship between the examined factors and E-learning System Effectiveness which indicate the strength of the examined relationships (Table 5). The assumptions of [48] including normality, linearity, homoscedasticity, and multicollinearity were examined before the regression analysis of the proposed hypotheses. Table 6 shows the regression analysis of examined factors.

Table 5. Correlation Coefficients of Examined Factors $(\mathrm{N}=129)$

\begin{tabular}{lc}
\hline Factors & (ESE) \\
\hline E-learning System Effectiveness (ESE) & 1 \\
System Quality (SQ) & $0.734(* *)$ \\
Information Quality (IQ) & $0.880(* *)$ \\
Service Quality (SEQ) & $0.825(* *)$ \\
Technical Support Quality (TSQ) & $0.811(* *)$ \\
Course Design Quality (CDQ) & $0.795(* *)$ \\
Learner Quality (LQ) & $0.869(* *)$ \\
\hline
\end{tabular}

$* * \mathrm{p}<.01$

As presented in Table 5, the results illustrate that the independent factors were strongly and positively correlated to other independent factors. The coefficient values range between $r=0.734$ to $r=0.880$ ( $\mathrm{n}=129, \mathrm{p} \quad .01$ ), which are considered to be high, positive, and strong correlations.
Table 6. Linear Regression Analysis between Independent and Dependent Factors

\begin{tabular}{lc|c|c|c|cr} 
& & \multicolumn{2}{c}{ Model Summary } \\
Model & $\mathrm{R}$ & R Square & $\begin{array}{c}\text { Adjusted R } \\
\text { Square }\end{array}$ & $\begin{array}{c}\text { Std. Error of the } \\
\text { Estimate }\end{array}$ & Sig. F Change & \\
\hline 1 & $.953^{\mathrm{a}}$ & .908 & .904 & .17061 & & .000 \\
\hline
\end{tabular}

\begin{tabular}{lllllll} 
& \multicolumn{5}{c}{ ANOVA $^{\mathbf{a}}$} \\
\hline Model & & Sum of Squares & df & Mean Square & F & Sig. \\
\hline 1 & Regression & 35.179 & 6 & 5.863 & 201.424 & $.000(\mathrm{a})$ \\
& Residual & 3.551 & 122 & .029 & & \\
& Total & 38.730 & 128 & & & \\
\hline
\end{tabular}

a. Predictors: (Constant), MTSQ, MSQ, MCDQ, MSEQ, MIQ, MLQ

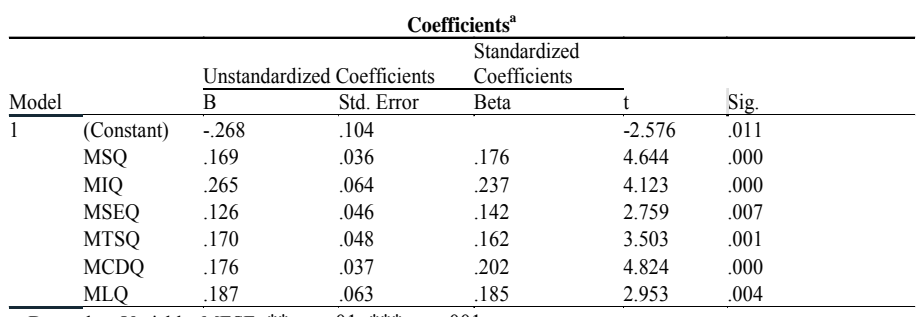

a. Dependent Variable: MESE, ${ }^{* *} \mathrm{p}<.01,{ }^{* * *} \mathrm{p}<.001$

The results of Table 6 indicated that the proposed examined factors significantly influenced E-learning System Effectiveness. The proposed factors explained a significant percentage of 90.8 of the total variance of E-learning System Effectiveness $(\mathrm{R} 2=.908, \mathrm{~F}(6,128)=201.424, \mathrm{p}<.01)$. Therefore, the examined alternative hypotheses $(\mathrm{H} 1-\mathrm{H} 6)$ were accepted. Table 7 shows a summary of tested hypotheses related to question 1 using the regression analysis.

Table 7. Summary of tested hypotheses results using liner regression analysis

\begin{tabular}{|c|c|c|}
\hline & Statement & Accepted/ Rejected \\
\hline $\mathrm{H}_{1}$ & System Quality has a positive influence on E-learning System Effectiveness. & Accepted \\
\hline $\mathrm{H}_{2}$ & Information Quality has a positive influence on E-learning System Effectiveness. & Accepted \\
\hline $\mathrm{H}_{3}$ & Service Quality has a positive influence on E-learning System Effectiveness. & Accepted \\
\hline $\mathrm{H}_{4}$ & $\begin{array}{l}\text { Technical Support Quality has a positive influence on E-learning System } \\
\text { Effectiveness. }\end{array}$ & Accepted \\
\hline $\mathrm{H}_{5}$ & $\begin{array}{l}\text { Course Design Quality has a positive influence on E-learning System } \\
\text { Effectiveness. }\end{array}$ & Accepted \\
\hline $\mathrm{H}_{6}$ & Learner Quality has a positive influence on E-learning System Effectiveness. & Accepted \\
\hline
\end{tabular}

The result of investigating factors related to DeLone \& McLean's ISS Model constructs, namely, System Quality, Information Quality, and Service Quality, has shown significant influence on E-learning System Effectiveness. The result is consistent with [33] who conducted research to investigate the effectiveness of e-learning portals. The researchers found that the Quality of System, the Quality of Information, and the Quality of Service have a significant effect on user satisfaction and ultimately affects e-learning portals' effectiveness. Moreover, the findings of this research were also consistent with [13] who developed the ISS model to investigate the quality and organisational factors that could influence e-learning system satisfaction. The results demonstrated that the quality-related factors including System Quality, Information Quality, and Quality of Service had a strong and positive effect on the quality satisfaction of e-learning systems. Similarly, the research [51] has proposed an elearning service framework in order to investigate the sustainability of learning and academic performance. The results revealed that, among many investigated factors, the Quality of the System and Information had a significant influence on e-learning service performance. 
The second research question tried to investigate the most contributed quality factors toward E-learning System Effectiveness. Therefore, the stepwise multiple regression technique was performed. The variation explained that E-learning System Effectiveness would be predicted using a stepwise regression predication equation using the standardized beta coefficient $(\beta)$, Adjusted R Square $\left(r^{2}\right)$, and Tvalue. Table 8 indicates the results of the stepwise multiple regression analysis.

Table 8. Stepwise Multiple Regression Analysis

\begin{tabular}{lcccccc}
\hline Factor & $\mathrm{R}^{2}$ & $\begin{array}{c}\text { Adjusted } \\
\mathrm{R}^{2}\end{array}$ & $\begin{array}{c}\text { Unstandardized } \\
\mathrm{B}\end{array}$ & $\begin{array}{c}\text { Standardized } \\
\text { Beta }\end{array}$ & $\mathrm{t}$ & $\mathrm{p}$. \\
\hline MSQ & .773 & .775 & .265 & .237 & 4.123 & .000 \\
MIQ & .841 & .843 & .126 & .142 & 2.759 & .007 \\
MSEQ & .867 & .870 & .176 & .202 & 4.824 & .000 \\
MTSQ & .904 & .908 & .187 & .185 & 2.953 & .004 \\
MCDQ & .898 & .902 & .170 & .162 & 3.503 & .001 \\
MLQ & .883 & .887 & .169 & .176 & 4.644 & .000 \\
\hline${ }^{2}$ Dependent Variable: MESE ${ }^{*} \mathrm{p}<.05{ }^{* *} \mathrm{p}<.01,{ }^{* * *} \mathrm{p}<.001$ & & &
\end{tabular}

As depicted in Table 8, the independent factors, namely, System Quality (SQ), Information Quality (IQ), Service Quality (SEQ), Technical Support Quality (TSQ), Course Design Quality (CDQ), and Learner Quality (LQ), were inserted into a regression predication equation using stepwise techniques. The extracted regression model utilized to predict E-learning System Effectiveness resulted in Adjusted R Square $=90.8 \%$ at a 0.01 significance level. All proposed factors activated positively the regression predication equation, and no single factor was excluded to enhance the variance of E-learning System Effectiveness. The most contributing factor toward E-learning System Effectiveness was Service Quality (SEQ) with $\beta=.202, \mathrm{t}=$ 4.824 , at the significance level of $p<.01$. The second contributing factor toward E-learning System Effectiveness was Learner Quality (LQ) with $\beta=.176, \mathrm{t}=4.644$, at the significance level of $\mathrm{p}<.01$. Furthermore, the third contributing factor toward E-learning System Effectiveness was System Quality (SQ) with $\beta=.237, \mathrm{t}=4.123$, at the significance level of $p<.01$. The fourth contributing factor toward E-learning System Effectiveness was Course Design Quality (CDQ) with $\beta=.162, t=3.503$. The fifth contributing factor toward E-learning System Effectiveness was Technical Support Quality (TSQ) with $\beta=.185, \mathrm{t}=2.953$, while the last contributing factor was Information Quality (IQ) with $\beta=.142, \mathrm{t}=2.759$.

The results of multiple regressions using stepwise analysis indicated that the top three contributing factors were Service Quality, Learner Quality, and System Quality respectively. In fact, Quality of Service has proven to be one of the most significant predictors of E-learning System Effectiveness, satisfaction, and usage in several proposed models and frameworks [52] - [53]. The recent research of [17] who proposed an extensive framework called the "EESS" Model, found that the Quality of Service influenced positively elearning system satisfaction. Similarly, the results also revealed that Learner Quality and System Quality influenced positively e-learning in the EESS Model. Nevertheless, limited research has found an inconclusive result regarding Service Quality which has no significant influence on e-learning usage and effectiveness [54].

The last research question sought to investigate the mediating effect of Attitude in the relationship between
Service Quality and E-learning System Effectiveness. Therefore, an alternative hypothesis was assumed: Attitude mediates positively the relationship between Service Quality and E-learning System Effectiveness. Hierarchical regression analysis and [55] technique were used to examine the mediation effect of Attitude in the relationship between Service Quality and E-learning System Effectiveness, as shown in Figure 4. According to Baron and Kenny's approach, the relationships between the targeted factors should be significantly correlated in order to run the hierarchical regression analysis.

Fig. 4 Mediation Model Using Baron \& Kenny’s Approach

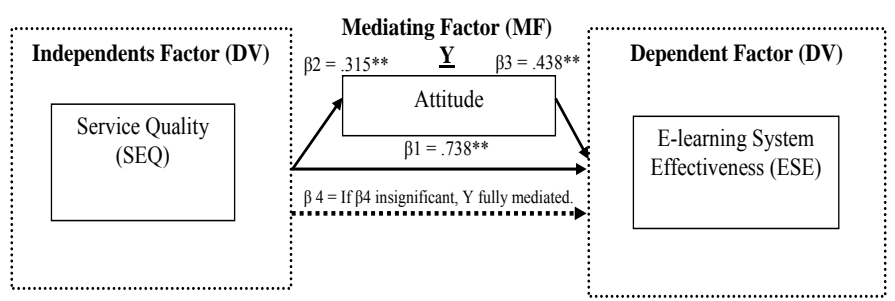

As presented in Figure 4, the correlation analysis indicated that the relationship between the examined factors has positive and significant relationships. Therefore, the hierarchical regression analysis could be performed. Table 9 reveals the results of the hierarchical regression analysis using Attitude as a mediator in the relationship between Service Quality and Elearning System Effectiveness.

Table 9. Hierarchical Regression of Mediating Analysis

\begin{tabular}{|c|c|c|c|c|c|c|}
\hline \multirow[t]{2}{*}{ Model } & & \multicolumn{2}{|c|}{$\begin{array}{c}\text { Unstandardized } \\
\text { Coefficients }\end{array}$} & \multirow{2}{*}{$\begin{array}{c}\begin{array}{c}\text { Standardized } \\
\text { Coefficients }\end{array} \\
\text { Beta } \\
\end{array}$} & \multirow[t]{2}{*}{$\mathrm{t}$} & \multirow[t]{2}{*}{ p. } \\
\hline & & B & Std. Error & & & \\
\hline \multirow{2}{*}{$\begin{array}{l}\text { Step1 } \\
\text { (Model 1) }\end{array}$} & (Constant) & 1.044 & .176 & & 5.936 & $.000^{* *}$ \\
\hline & Service Quality & .680 & .055 & .738 & 12.343 & $.000^{* *}$ \\
\hline \multirow{3}{*}{$\begin{array}{l}\text { Step2 } \\
\text { (Model 2) }\end{array}$} & (Constant) & .552 & .211 & & 2.611 & $.010^{*}$ \\
\hline & Service Quality & .614 & .055 & .667 & 11.121 & $.000^{* *}$ \\
\hline & Attitude & .221 & .058 & .228 & 3.810 & $.000^{* *}$ \\
\hline
\end{tabular}

As portrayed in Table 9, the results designate that, in the first model, Service Quality contributed significantly to Elearning System Effectiveness: R2 $=0.545$, F $(1,128)=152.3$, $\mathrm{p}<.05$. Model 1 indicates that Service Quality was positively related to E-learning System Effectiveness at the significance level of $\mathrm{p}<.01: \beta=.738, \mathrm{t}=12.343$. In model 2 , Attitude was inserted into the equation; the $\mathrm{R} 2=0.592$ changed significantly with $\mathrm{F}(2,128)=91.5, \mathrm{p}<.05$. Model 2 shows that Service Quality was insignificantly reduced at the significance level of $\mathrm{p}<.01: \beta=.667 \mathrm{t}=11.121$. According to Baron and Kenny's approach, partial mediation occurred when the mediating factor entered the equation in model 2 and reduced insignificantly the relationship between the independent factor and the dependent factor. Therefore, the alternative hypothesis was accepted, and Attitude partially mediated the relationship between Service Quality and Elearning System Effectiveness. Unfortunately, the research investigating the role of the mediating effect of Attitude on influencing the relationship between Service Quality and E- 
learning System Effectiveness was limited. However, much research has investigated the mediation role of Attitude on the relationship between System Quality and e-learning satisfaction and proved to be positively significant (Civelek et al., 2016). The direct effect of Service Quality on Attitude has been confirmed in addition to the direct effect of Attitude on E-learning System Effectiveness [13]- [33]- [24]- [56].

\section{CONCLUSION, IMPLICATIONS, AND RECOMMENDATIONS}

The aim of this research was to investigate the influence of the proposed factors, namely, System Quality (SQ), Information Quality (IQ), Service Quality (SEQ), Learner Quality (LQ), Course Design Quality (CDQ), and Technical Support Quality (TSQ), on E-learning System Effectiveness. Furthermore, the mediating role of Attitude in the relationship between Service Quality and E-learning System Effectiveness was investigated. The research has proposed a theoretical model by adopting the ISS model's independent constructs and extending them to include additional factors and investigate the mediating role of Attitude. The results revealed that the proposed examined factors influenced significantly E-learning System Effectiveness. The results of the stepwise multiple regression analysis indicated that the top three contributed factors were respectively Service Quality, Learner Quality, and System Quality. Furthermore, Attitude was found to partially mediate the relationship between Service Quality and Elearning System Effectiveness.

Theoretically, the proposed model showed strong validity in terms of its related testing factors and significant percentage $(90.8 \%)$ of the total variance of E-learning System Effectiveness. It could include additional factors in future research. However, it needs more validations in different universities and scopes. It is recommended for future research to investigate additional factors as antecedents to proposed factors. This research investigated the mediating role of Attitude in influencing the relationship between Service Quality and E-learning System Effectiveness, which could be considered as adding value to the body of literature due to the limitations of current research. It also gives future research the opportunity to investigate Attitude as a moderator or mediator for other significant factors shown in this research. This research is limited to the ISS model and other well-cited factors, and it is therefore recommended for future research to integrate different models and theories to investigate and validate different factors that could influence E-learning System Effectiveness using different research approaches.

In terms of practical implications, E-learning System Effectiveness is an essential part of any successful implementation and use of e-learning. Hence, the investigated factors should be taken into consideration by the university decision-makers, e-learning designers, and IT developers when designing and implementing e-learning systems in order to ensure their effectiveness. It is also recommended to reevaluate the current e-learning system in terms of Service Quality, Learner Quality, and System Quality and to ensure that all examined significant factors are effectively achieved.

The research is limited to academic staff and by the sample size, theoretical foundations, and quantitative approach.
Therefore, it is recommended for future research to investigate E-learning System Effectiveness from different perspectives such as those of e-learning designers and students in different universities and to maximize the sample size. Moreover, future research could investigate the issue of using different models and theories to include additional validated factors that could influence E-learning System Effectiveness using different research approaches and analyses.

\section{References}

[1] Shahzad, A., Hassan, R., Aremu, A. Y., Hussain, A., \& Lodhi, R. N. (2020). Effects of COVID-19 in E-learning on higher education institution students: the group comparison between male and female. Quality \& quantity, $1-22$.

[2] Almaiah, M. A., Al-Khasawneh, A., \& Althunibat, A. (2020). Exploring the critical challenges and factors influencing the E-learning system usage during COVID19 pandemic. Education and Information Technologies, 1.

[3] Sahu, P. (2020). Closure of universities due to coronavirus disease 2019 (COVID-19): impact on education and mental health of students and academic staff. Cureus, 12(4).1-6.

[4] Layali, K., \& Al-Shlowiy, A. (2020). Students' perceptions of e-Learning for ESL/EFL in Saudi Universities and their implications during Coronavirus Pandemic: A review of literature. International Journal of English Language \& Translation Studies, 8(1), 64-72.

[5] Prestiadi, D. (2020). Effectiveness of e-learning implementation as a distance learning strategy during coronavirus disease (covid-19) pandemic International webinar on education.47-53.

[6] Alshehri, Y. A., Mordhah, N., Alsibiani, S., Alsobhi, S., \& Alnazzawi, N. (2020). How the Regular Teaching Converted to Fully Online Teaching in Saudi Arabia during the Coronavirus COVID-19. Creative Education, 11(7), 985-996.

[7] Alqahtani, A. Y., \& Rajkhan, A. A. (2020). E-Learning Critical Success Factors during the COVID-19 Pandemic: A Comprehensive Analysis of E-Learning Managerial Perspectives. Education Sciences, 10(9), 216-229.

[8] Al-Okaily, M., Alqudah, H., Matar, A., Lutfi, A., \& Taamneh, A. (2020). Dataset on the Acceptance of elearning System among Universities Students' under the COVID-19 Pandemic Conditions. Data in brief, 32, 106176.

[9] Chen, T., Peng, L., Yin, X., Rong, J., Yang, J., \& Cong, G. (2020, September). Analysis of User Satisfaction with Online Education Platforms in China during the COVID19 Pandemic. In Healthcare (Vol. 8, No. 3, p. 200). Multidisciplinary Digital Publishing Institute.

[10]Diab, G. M. A. E. H., \& Elgahsh, N. F. (2020). E-learning During COVID-19 Pandemic: Obstacles Faced Nursing Students and Its Effect on Their Attitudes While Applying It. American Journal of Nursing, 9(4), 300-314.

[11] Hoq, M. Z. (2020). E-Learning during the period of pandemic (COVID-19) in the kingdom of Saudi Arabia: 
an empirical study. American Journal of Educational Research, 8(7), 457-464.

[12] Pham, L., Kim, K., Walker, B., DeNardin, T., \& Le, H. (2019). Development and Validation of an Instrument to Measure Student Perceived E-Learning Service Quality. International Journal of Enterprise Information Systems (IJEIS), 15(2), 15-42.

[13] Alkhalaf, S., Nguyen, A., Drew, S., \& Jones, V. (2013). Measuring the Information Quality of ELearning Systems in KSA: Attitudes and Perceptions of Learners. In J. Kim, E. Matson, H. Myung, \& P. $\mathrm{Xu}$, Advances in Intelligent Systems and Computing(Vol. 208, pp. 787-791). Berline, Heidelberg: Springer.

[14] AlMulhem, A. (2020). Investigating the effects of quality factors and organisational factors on university students' satisfaction of e-learning system quality. Cogent Education, 7(1), 1-16.

[15] Dhawan, S. (2020). Online learning: A panacea in the time of COVID-19 crisis. Journal of Educational Technology Systems, 49(1), 5-22.

[16] Almaiah, M. A., \& Almulhem, A. (2018). A conceptual framework for determining the success factors of elearning system implementation using Delphi technique. Journal of Theoretical and Applied Information Technology, 96(17).

[17] Al-Fraihat, D., Joy, M., \& Sinclair, J. (2020). Evaluating E-learning systems success: An empirical study. Computers in Human Behavior, 102, 67-86.

[18] Hadoussa, S. (2020). Evaluation of e-learning system on higher education institutions in KSA: a survey at Saudi Electronic University. International Journal of Technology Enhanced Learning, 12(2), 180-199.

[19] Seliana, N., Suroso, A. I., \& Yuliati, L. N. (2020). Evaluation of E-Learning Implementation in The University Using Delone And Mclean Success Model. Jurnal Aplikasi Manajemen, 18(2), 345-352.

[20] Delone, W. H., \& McLean, E. R. (2003). The DeLone and McLean Model of Information Systems Success: TenYear Update. Journal of management information systems, 19(4), 9-30.

[21] Abdulhameed Rakan Alenezi (2017). Applying Theory of Planned Behavior (TPB) to investigate factors affecting academic staffs' intention toward using e-assessment as evaluation tools in online courses. Al-jouf Social Sciences Journal (ASSJ).3(2).191-207.

[22] Cidral, W. A., Oliveira, T., Di Felice, M., \& Aparicio, M. (2018). E-learning success determinants: Brazilian empirical study. Computers \& Education, 122, 273-290.

[23] Naveed, Q. N., Muhammad, A., Sanober, S., Qureshi, M. R. N., \& Shah, A. (2017). A mixed method study for investigating critical success factors (CSFs) of e-learning in Saudi Arabian universities. methods, 8(5), 171-178.

[24] Osman, M. A. F., Wahid, A., \& Zakria, A. (2018). Assessment of factors affecting e-learning: preliminary investigation. In 1st International Conference on Open Library to Open SocietyAt: Sukhotai Thammatirat Open University, Nonthaburi, Thailand.
[25] Mamun, M. A., Chandrima, R. M., \& Griffiths, M. D. (2020). Mother and son suicide pact due to COVID-19related online learning issues in Bangladesh: An unusual case report. International Journal of Mental Health and Addiction, 1-4.

[26] Alharbi, H., \& Sandhu, K. (2019). New discoveries for user acceptance of e-learning analytics recommender systems in Saudi Arabia. International Journal of Innovation in the Digital Economy (IJIDE), 10(1), 31-42.

[27] World Bank (2020). How countries are using edtech (including online learning, radio, television, texting) to support access to remote learning during the COVID-19 pandemic. Available

https:/www.worldbank.org/en/topic/edutech/brief/howcountries-are-using-edtech-to-support-remote-learningduring-the-covid-19-pandemic (Accessed on 29 Sep., 2020).

[28] Abdulrahim, H., \& Mabrouk, F. (2020). COVID-19 and the Digital Transformation of Saudi Higher Education. Asian Journal of Distance Education, 15(1), 291-306.

[29]Frokjaer, E., Hertzum, M., Hornbaek, K., 2000. Measuring usability: are effectiveness, efficiency, and satisfaction really correlated? In: Proceedings of the ACM CHI 2000 Conference on Human Factors in Computing Systems 2(1), pp. 345-352.

[30]Bhatia R.P (2011). Features and effectiveness of elearning tools. Global J Business Managemnt Inform Tech. 1(2), 1-7.

[31] Oztekin, A., Kong, Z. J., \& Uysal, O. (2010). UseLearn: A novel checklist and usability evaluation method for eLearning systems by criticality metric analysis. International Journal of Industrial Ergonomics, 40(4), 455-469.

[32] Al-Jedaiah, M. (2020). Knowledge management and elearning effectiveness: Empirical evidence from Jordanian Higher Education Institutions. International Journal of Emerging Technologies in Learning (iJET), 15(5), 50-62.

[33] Chopra, G., Madan, P., Jaisingh, P., \& Bhaskar, P. (2019). Effectiveness of E-learning portal from students' perspective: A structural equation model (SEM) approach. Interactive Technology and Smart Education 16(2), 94116.

[34] Nariman, D. (2020, July). Impact of the Interactive eLearning Instructions on Effectiveness of a Programming Course. In Conference on Complex, Intelligent, and Software Intensive Systems (pp. 588-597). Springer, Cham.

[35] Teo, T. S., Kim, S. L., \& Jiang, L. (2020). E-learning implementation in south Korea: Integrating Effectiveness and Legitimacy Perspectives. Information Systems Frontiers, 22(2), 511-528.

[36] Zaineldeen, S., Hongbo, L., \& Koffi, A. L. (2020). Review of The DeLone and McLean Model of Information Systems Success' Background and it's An application in The Education Setting, and Association Linking with Technology Acceptance Model. International Journal of Research in Social Sciences, 10(09). 27-42. 
[37] Martin, F., Bolliger, D. U., \& Flowers, C. (2021). Design Matters: Development and Validation of the Online Course Design Elements (OCDE) Instrument. The International Review of Research in Open and Distributed Learning, 22(2), 46-71.

[38] McMahon, E. (2021). Designing Effective Online Courses: Exploring the Relationships Amongst Teaching Self-efficacy, Professional Development, Faculty Experience, and Implementation of Effective Online Course Design Practices. [Doctoral dissertation, Minnesota State University Moorhead], Repository of Digital Collections.

[39] Masoumi, D., \& Lindström, B. (2012). Quality in e-learning: a framework for promoting and assuring quality in virtual institutions. Journal of Computer Assisted Learning, 28(1), 27-41.

[40] O'Keefe, L., Dellinger, J. T., Scragg, B., Amelina, N., \& Mathes, J. (2020). The State of Online Learning in the Kingdom of Saudi Arabia: A COVID-19 Impact Study for K-12. Online Learning Consortium.

[41] Elumalai, K. V., Sankar, J. P., Kalaichelvi, R., John, J. A., Menon, N., Alqahtani, M. S. M., \& Abumelha, M. A. (2021). Factors Affecting the Quality of E-Learning During the COVID-19 Pandemic from the Perspective of Higher Education Students. COVID-19 and Education: Learning and Teaching in a Pandemic-Constrained Environment, 167- 189.

[42] Alenezi, A. R. (2017). Factors affecting the quality of online courses in newly established universities in Saudi Arabia: Academic Staff perspective. International journal of instructional technology and distance learning (14)4. 103-116.

[43] Olatokun, W., \& Ntemana, T. (2015). Information and communication technology (ICT) use by lecturers at the National University of Lesotho. Indian Journal of Library and Information Science, 9(1), 5-20.

[44] Mardiana, S., Tjakraatmadja, J. H., \& Aprianingsih, A. (2015). DeLone-McLean information system success model revisited: The separation of intention to use-use and the integration of technology acceptance models. International Journal of Economics and Financial Issues, 5(1S).172-182.

[45] Pardiñan, E., \& Loremia, R. (2019). Simulation-Based Learning in Electronics: Modified TAM and DeLone \& McLean IS Success Model. Journal of educational and human resource development, 7, 84-100.

[46] Lee, J. (2010). Online support service quality, online learning acceptance, and student satisfaction. The Internet and Higher Education, 13(4), 277-283.

[47] Ramayah, T., \& Lee, J. W. C. (2012). System characteristics, satisfaction and e-learning usage: a structural equation model (SEM). Turkish Online Journal of Educational Technology-TOJET, 11(2), 196-206.

[48] Hair, J. F., Anderson, R. E., Babin, B. J., \& Black, W. C. (2010). Multivariate data analysis: A global perspective (Vol. 7): Pearson Upper Saddle River, NJ.
[49] Brzoska, P., \& Razum, O. (2010). Validity issues in quantitative migrant health research: The example of illness perceptions (Vol. 58). Peter Lang.

[50] Coakes, S., Steed, L. \& Ong., O (2010). SPSS Version 18.0 Analysis without Anguish.

[51] Alam, M. M., Ahmad, N., Naveed, Q. N., Patel, A., Abohashrh, M., \& Khaleel, M. A. (2021). E-learning services to achieve sustainable learning and academic performance: An empirical study. Sustainability, 13(5), 2640-2653.

[52] Tj, H. W., \& Tanuraharjo, H. H. (2020). The Effect Of Online Learning Service Quality On Student Satisfaction During COVID19 Pandemic In 2020. Journal Management Indonesia, 20(3), 240-251.

[53]Zolotov, M. N., Oliveira, T., \& Casteleyn, S. (2018). Continued intention to use onlineparticipatory budgeting: The effect of empowerment and habit.Proceedings of the 11thinternational conference on theory and practice of electronic governance-ICEGOV‘18(pp. 209-216).

[54] Seta, H.B, Wati, H., Muliawati, A. \& Hidayanto, A.N. (2018). E-Learning Success Model: An Extention of DeLone \& McLean IS' Success Model. Indonesian Journal of Electrical Engineering and Informatics (IJEEI), 6(3).281-291.

[55]Baron, R. M., \& Kenny, D. A. (1986). The moderatormediator variable distinction in social psychological research: Conceptual, strategic, and statistical considerations. Journal of personality and social psychology, 51(6), 1173-1182.

[56] Seliana, N., Suroso, A. I., \& Yuliati, L. N. (2020). Evaluation of E-Learning Implementation in The University Using Delone And Mclean Success Model. Jurnal Aplikasi Manajemen, 18(2), 345-352.

\section{Creative Commons Attribution License $\mathbf{4 . 0}$ (Attribution 4.0 International, CC BY 4.0)}

This article is published under the terms of the Creative Commons Attribution License 4.0

https://creativecommons.org/licenses/by/4.0/deed.en_US 